\title{
Rapid deposition of amyloid in human islets transplanted into nude mice
}

\author{
P. Westermark ${ }^{1}$, D. L. Eizirik ${ }^{2}$, D. G. Pipeleers ${ }^{3}$, C. Hellerström² ${ }^{2}$ A. Andersson ${ }^{2}$ \\ ${ }^{1}$ Department of Pathology, Linköping University, Linköping, Sweden \\ ${ }^{2}$ Department of Medical Cell Biology, Uppsala University, Uppsala, Sweden \\ ${ }^{3}$ Department of Metabolism and Endocrinology, Vrije Universiteit Brussel and $\beta$-Cell Transplant, Brussels, Belgium
}

\begin{abstract}
Summary Human islets of Langerhans were transplanted to the subcapsular space of the kidneys of nude mice which were either normoglycaemic or made diabetic with alloxan. After 2 weeks, the transplants were processed for light and electron microscopical analyses. In all transplants, islet amyloid polypeptide (IAPP)-positive cells were found with highest frequency in normoglycaemic animals. IAPP-positive amyloid was seen in 16 out of 22 transplants ( $73 \%$ ), either by polarisation microscopy after Congo red staining or by immune electron microscopy. At variance with previous findings of amyloid deposits exclusively in the extracellular space of islets of non-insulin-dependent diabetic patients, the grafted
\end{abstract}

islets contained intracellular amyloid deposits as well. There was no clear difference in occurrence of amyloid between diabetic and non-diabetic animals. The present study indicates that human islets transplanted into nude mice very soon present IAPP-positive amyloid deposits. This technique may provide a valuable model for studies of the pathogenesis of islet amyloid and its impact on islet cell function. [Diabetologia (1995) 38: 543-549]

Key words Islet amyloid polypeptide, human pancreatic islets, islet transplantation, immune histochemistry, hyperglycaemia.
Islet beta cells synthesize and secrete not only insulin but also several other polypeptides. Thus, islet amyloid polypeptide (IAPP or "amylin") is normally stored together with insulin in the secretory granules and the two products are released together. IAPP is a 37 amino acid hormone-like polypeptide with significant homology with the neuropeptide calcitonin gene-related peptide (CGRP) [1-3]. Although IAPP induces substantial effects on glucose metabolism, calcium metabolism and food intake under experimental conditions, no definite role has been attributed to the peptide in human physiology or in diabetes mellitus [4].

Received: 9 September 1994 and in revised form: 22 November 1994

Corresponding author: Professor P. Westermark, Department of Pathology, University Hospital, S-58185 Linköping, Sweden Abbreviations: IAPP, Islet amyloid polypeptide, NIDDM, noninsulin-dependent diabetes mellitus.
Islet amyloid fibrils are polymers of IAPP and deposition of amyloid in the islets of Langerhans is the most characteristic morphological lesion in non-insulin-dependent diabetes mellitus (NIDDM). Islet amyloid is formed in close association with beta cells and accumulates extracellularly. The exact place for formation has not been defined and both extracellular [5] and intracellular [6] polymerisation has been proposed. Islet amyloid is not pathognomonic for diabetes, since it also occurs as an age-related phenomenon in non-diabetic individuals [7-10]. The proportion of islets with amyloid varies highly but on average $50 \%$ of the islets in the corpus and the cauda of the pancreas in NIDDM patients are affected [11]. A certain number of NIDDM patients, however, lack or have very little islet amyloidosis and this has led to the conclusion that islet amyloid is probably of minor importance for a defective islet function. In some individuals the degree of islet amyloidosis is nevertheless pronounced with a substantial loss of beta cells [12] and at least in these cases it is reason- 
Table 1. Material from transplanted human islets, studied light microscopically for IAPP-positive cells and deposits of amyloid

\begin{tabular}{|c|c|c|c|c|c|}
\hline $\begin{array}{l}\text { Trans- } \\
\text { plant } \\
\text { No. }\end{array}$ & $\begin{array}{l}\text { Donor } \\
\text { pancreas } \\
\text { No. }\end{array}$ & $\begin{array}{l}\text { Age of } \\
\text { donor } \\
\text { (years) }\end{array}$ & $\begin{array}{l}\text { Alloxan } \\
\text { treatment }\end{array}$ & $\begin{array}{l}\text { IAPP } \\
\text { cells } \\
(\%)\end{array}$ & $\begin{array}{l}\text { Amy- } \\
\text { loid }\end{array}$ \\
\hline H 1 & 38 & 57 & no & 70 & + \\
\hline $\mathrm{H} 2$ & 39 & 18 & no & 70 & n.d. \\
\hline H 3 & 38 & 57 & no & 50 & + \\
\hline $\mathrm{H} 4$ & 38 & 57 & yes $^{a}$ & 40 & + \\
\hline $\mathrm{H} 5$ & 40 & 45 & yes & 25 & - \\
\hline $\mathrm{H} 6$ & 40 & 45 & no & 50 & + \\
\hline $\mathrm{H} 7$ & 40 & 45 & no & 70 & n.d. \\
\hline $\mathrm{H} 8$ & 41 & 18 & $\operatorname{yes}^{\mathrm{a}}$ & 40 & + \\
\hline $\mathrm{H} 9$ & 41 & 18 & yes $^{a}$ & 60 & - \\
\hline H10 & 41 & 18 & no & 60 & + \\
\hline $\mathrm{H} 12$ & 42 & 22 & yes & 50 & - \\
\hline $\mathrm{H} 14$ & 42 & 22 & no & 35 & - \\
\hline $\mathrm{H} 15$ & 43 & 48 & yes & 10 & + \\
\hline $\mathrm{H} 16$ & 43 & 48 & yes & 5 & n.d. \\
\hline $\mathrm{H} 17$ & 43 & 48 & no & 70 & n. d. \\
\hline $\mathrm{H} 18$ & 44 & 64 & yes & 30 & + \\
\hline H19 & 44 & 64 & no & 35 & n.d. \\
\hline
\end{tabular}

n. d.: not studied due to lack of material. ${ }^{\mathrm{a}}$ Initially diabetic animal but recovered to normoglycaemia after transplantation

able to postulate an influence of the amyloid on islet function. Up to now, a detailed study of the pathophysiological relevance of amyloid has been hampered by the lack of an appropriate animal model to reproduce this phenomenon.

The present study was therefore performed for two main reasons. First, we wanted to study the expression of IAPP in transplanted human islets. Second, we were interested in investigating whether islet amyloid can develop in transplanted human islets, in which case they could serve as an experimental model for the study of the pathogenesis of islet amyloidosis.

\section{Materials and methods}

Human islet preparation. Thirteen human pancreata excised from organ donors (Tables 1 and 2) were transported to and used for islet isolation at the Central Unit of the beta-cell Transplant, Brussels as recently described in detail [13-14]. Aliquots of the islet-enriched fraction examined by electron microscopy were found to contain $6 \pm 1 \%$ dead cells and $2 \pm 1 \%$ acinar cells. Light microscopical examinations of immuno cytochemically-stained islets revealed that $46 \pm 3 \%$ of the islet cells were insulin positive and $8 \pm 1 \%$ glucagon positive. The islet insulin content was $1.17 \pm 0.08 \mathrm{ng}$ of insulin per $\mathrm{ng}$ of DNA. The isolated islets were cultured for $5 \pm 1$ days in Ham's F-10 medium containing $6.1 \mathrm{mmol} / 1$ glucose [13] before being sent to Uppsala by air in the same medium. There they were cultured in RPMI 1640 medium containing $5.6 \mathrm{mmol} / 1$ glucose for 5-7 days before transplantation [13].

Light microscopy studies. The light microscopy studies were performed on 17 mice with islet transplants originating from
Table 2. Material from transplanted human islets, studied electron microscopically for deposits of amyloid extra- or intracellularly

\begin{tabular}{lllll}
\hline $\begin{array}{l}\text { Transplant } \\
\text { No. }\end{array}$ & $\begin{array}{l}\text { Donor } \\
\text { pancreas } \\
\text { No. }\end{array}$ & $\begin{array}{l}\text { Age of } \\
\text { donor } \\
\text { (years) }\end{array}$ & $\begin{array}{l}\text { Alloxan } \\
\text { treatment }\end{array}$ & Amyloid \\
\hline 1 & 62 & 42 & no & + \\
2 & 62 & 42 & yes & - \\
3 & 61 & 10 & no & - \\
5 & 63 & 30 & no & + \\
7 & 65 & 18 & yes & + \\
8 & 65 & 18 & no & + \\
9 & 66 & 53 & no & + \\
10 & 66 & 53 & yes & + \\
11 & 67 & 58 & no & + \\
12 & 67 & 58 & yes & + \\
\hline
\end{tabular}

${ }^{a}$ Initially diabetic animal but recovered to normoglycaemia after transplantation

seven adult organ donors (mean age $39 \pm 7$ years, range 18 64 years, Table 1). Each nude mouse (nu/nu; Bomholdtgaard, $\mathrm{Ry}$, Denmark) had islets implanted under the left renal capsule in numbers (about 300) usually not high enough to cure alloxan-diabetic recipients [14]. Five to 7 days before transplantation, eight animals received alloxan i.v. $(80 \mathrm{mg} / \mathrm{kg}$ body weight). Glucose determinations were performed by means of an Exatech Blood Glucose Meter (Baxter Travenol, Deerfield, Ill., USA) on blood samples taken from the tail tip. Two weeks after transplantation, the animals were killed by cervical dislocation and the transplant harvested for further investigations. For light microscopy, tissue was fixed in buffered neutral formalin and embedded in paraffin. Deparaffinized sections were stained with Congo red and studied in a polarisation microscope for amyloid. Sections from the donor pancreata, used in the light microscopy study, were also studied for the presence of amyloid in the same way.

Electron microscopy studies. These studies were performed on ten animals with subcapsular islet transplants originating from six donors (mean age $35 \pm 8$ years, range 10-58) (Table 2 ). Induction of diabetes and islet transplantation were performed as described above. The animals were killed after 2 weeks by cervical dislocation and the entire transplant was immediately excised and fixed for $6 \mathrm{~h}$ in $2.5 \%$ glutaraldehyde in $0.1 \mathrm{~mol} / \mathrm{l}$ sodium phosphate buffer, $\mathrm{pH}$ 7.4. Thereafter, it was dehydrated and embedded in Epon.

Immunohistochemistry and immune electron microscopy. Rabbit antiserum to rat/mouse IAPP (A110) has been characterised previously [15]. Antiserum to human IAPP20-29 (A133) was obtained by immunisation of a rabbit with synthetic human IAPP20-29, linked to keyhole limpet haemaocyanin. This antiserum reacts with human but not mouse islet betacells and the reaction is abolished by preabsorbtion of the antiserum with an excess of IAPP20-29. Guinea pig antiserum to porcine insulin (Ma37) has also been described earlier [15]. Adjacent sections (when available) were immunohistochemically labelled with these antisera as described [16] using the peroxidase-antiperoxidase method [17]. For negative controls, the IAPP antisera were replaced by corresponding nonimmune serum. Immunostaining for the quantitative studies was performed in two batches and included a section of human pancreas containing islets with known strong $(+++$, see below) IAPP-immunoreactivity. 


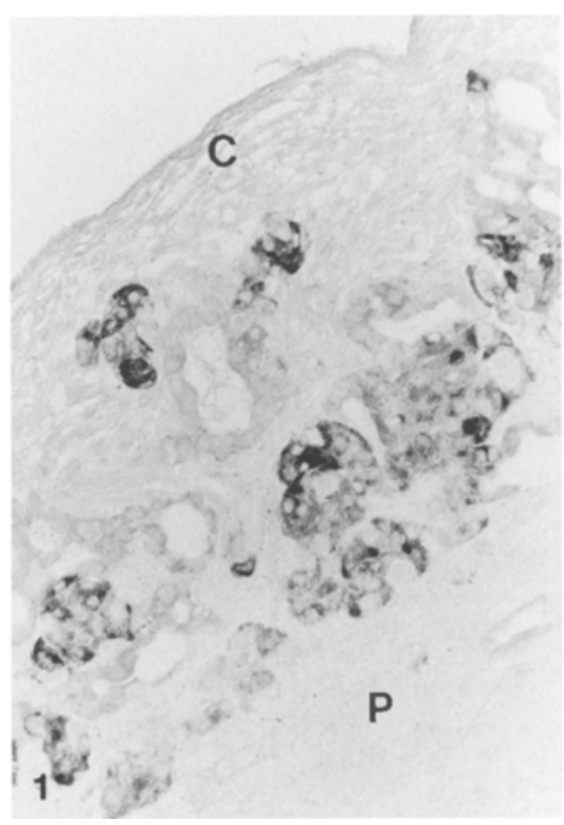

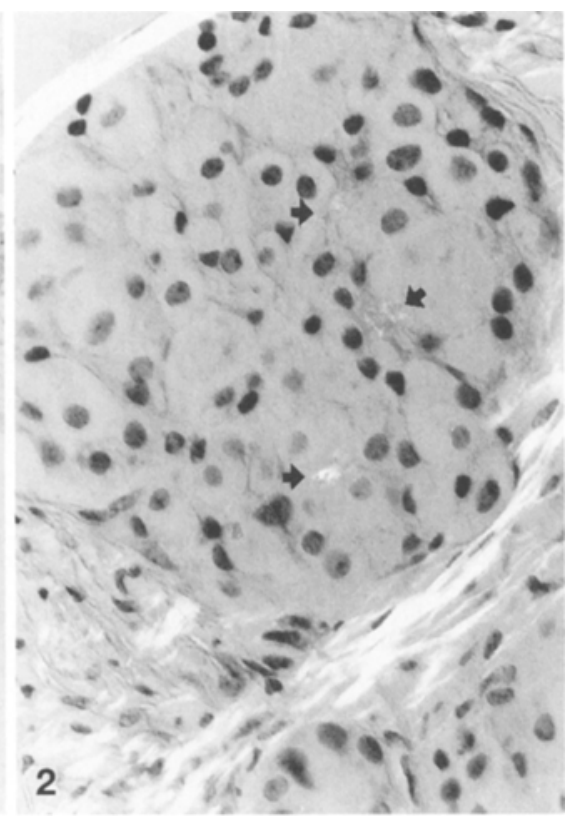

Fig.1. Human islet transplant showing many IAPP-expressing cells. Many small duct-like structures are also evident. C, kidney capsule; P, kidney parenchyma. Antiserum to IAPP, peroxidase-antiperoxidase technique. $\times 200$

Fig. 2. Human islet transplant stained with Congo red and viewed under polarized light. Scattered small birefringent amyloid deposits (arrows), presumably extracellular, are seen. $\times 450$
For evaluation of the frequencies and staining intensity of IAPP-positive cells, slides labelled with antiserum A110 were read blindly by one investigator. The mean strength of IAPP labelling was assessed according to a semiquantitative scale $(+-+++)$. In the same sections, the percentage of IAPP-positive islet cells was determined as well as the percentage of strongly $(+++)$ IAPP-positive cells.

For electron microscopy, ultrathin sections were mounted on formvar-coated nickel grids and immunolabelled as described previously [18]. Shortly, sections were incubated with the primary antiserum, diluted $1: 25-1: 50$ (A110 and A133) or 1:200 (Ma37). After washing and blocking, the binding was visualised with protein A-coated 10 -nm gold particles (Bio Cell, Cardiff, UK). The sections were then contrasted with $4 \%$ uranyl acetate and $2 \%$ lead citrate and examined in a Jeol $100 \mathrm{SX}$ electron microscope.

\section{Statistical analysis}

Data are given as mean $\pm S E M$ and statistical significance was analysed by the Mann-Whitney non-parametric test.

\section{Results}

Light microscopy. In the light microscopy series of 17 animals, eight were treated with alloxan. Five of them remained diabetic (blood glucose concentration $23.8 \pm 0.9 \mathrm{mmol} / \mathrm{l}$ ), while three became normoglycaemic after islet transplantation. The human islet graft was located beneath the kidney capsule and mostly appeared as distinctive islets in a faint connective tissue stroma. Irregular duct-like structures occurred among the islets in the transplants in both normoglycaemic and hyperglycaemic animals (Fig. 1). In many transplants, some degenerative changes were evident, most commonly as vacuolisat- ion of the endocrine cells. This was seen both in normoglycaemic and hyperglycaemic animals.

Occurrence of IAPP-positive cells. Light microscopically, insulin and IAPP-positive cells were observed in all transplants in normoglycaemic animals. Usual$1 y$, a majority of cells were evenly labelled with the insulin antibody. Also antiserum to IAPP labelled most endocrine cells (Fig. 1) and there was no difference in labelling pattern between the two antisera used (A110 and A133). Comparisons of adjacent sections stained for IAPP and insulin, respectively, indicated that the antisera stained the same cells. A difference between the labelling with the antisera was obvious, however, in that the intensity of staining between cells varied much more after labelling with the antiserum to IAPP compared to sections stained for insulin. Thus, while the insulin-staining was fairly even, both strongly and weakly labelled cells occurred after staining for IAPP. Scattered insulin- and IAPP-positive cells were also seen in the small duct-like formations.

Also in the animals with hyperglycaemia, all islet transplants contained insulin and IAPP immunoreactive cells. The percentage of IAPP-positive cells was lower in the islet grafts of the five hyperglycaemic mice as compared with the nine normoglycaemic mice not treated with alloxan (24 \pm 8 vs $54 \pm 4 \%$; $p<0.01$, Table 1). Furthermore, the IAPP-labelling of cells generally seemed weaker compared to cells in transplants from normoglycaemic animals although the difference was not statistically significant $(p<0.08)$. Like transplants in normoglycaemic mice, both weakly and strongly stained IAPP-labelled cells occurred, but the number of strongly positive cells tended to be lower in the hyperglycaemic animals $(7 \pm 3$ vs $16 \pm 4 \% ; p=0.06)$. 
Congo red staining for determination of amyloid. Sections of transplants from 12 mice (four hyperglycaemic and eight normoglycaemic, Table 1) were evaluated. These transplants originated from six different donor pancreata. Amyloid was demonstrated in the human islet transplants of eight $(67 \%)$ animals, of which six were normoglycaemic and two hyperglycaemic. Two of the transplants retrieved from hyperglycaemic mice and two of the transplants from the normoglycaemic animals lacked amyloid.

In most cases, multiple, small amyloid deposits were seen (Fig. 2). Sometimes, these seemed to be extracellular but small and very faintly stained deposits were obviously present also in the cytoplasm of islet cells. In only one transplant did slightly larger amyloid deposits occur. The amyloid was labelled with antibodies against human IAPP (Fig. 3) but not with insulin antibodies. No amyloid or IAPP-positive material was seen outside the islet tissue.

Sections of the six donor pancreata (collected before the pancreata were processed for islet isolation) used for the transplantation experiments described above were investigated for amyloid after staining with Congo red. In all instances, the histological appearance was normal and no amyloid was seen in any of the studied islets.

Electron microscopy. Electron microscopy investigations were performed on ten transplants from four alloxan-diabetic and six normoglycaemic animals. Three mice were hyperglycaemic at death $(23 \pm 1.2 \mathrm{mmol} / \mathrm{l})$, while one had become almost normoglycaemic $(9.7 \mathrm{mmol} / \mathrm{l})$. The transplanted islets were from six different donor pancreata (Table 2).

Alpha, beta and delta-cells were easily recognised by their typical secretory granules. While alpha and delta cells always were heavily granulated, degranulated beta cells were common in both diabetic and non-diabetic animals. In some beta cells, only very few granules were found. IAPP and insulin immunoreactivity was seen only in beta cells while alpha and delta cells were negative (Fig.4). The labelling was confined to the secretory granules with gold particles mainly on the cores as previously described [19] (Fig.4). The degree of IAPP-labelling of the betacell granules did not vary between different cells. IAPP and insulin antisera labelled most of the granules in a similar way.

Accumulation of amyloid material, strongly labelled with antiserum to IAPP (but not to insulin), was found in eight of the 12 transplants (Table 2). This material sometimes had a granular appearance while in other areas a fibrillar structure was apparent (Fig.5). The fibrils were usually thin and wavy while more straight fibrils occurred more rarely. Most of the material was found within cells which exhibited severe degenerative changes in the form of vacuoles and loss of the normal cellular structure. The cells usually, but not always, contained a few granules of beta-cell type that were only weakly labelled with IAPP antiserum. Small extracellular deposits were also seen and sometimes it was impossible to determine whether a deposit was extra- or intracellular. Except for minor deposits, the intracellular amyloid usually formed a network giving the impression of being laid down in a preformed compartment, which in some areas was highly suggestive of endoplasmic reticulum (Fig. 5). The exact localisation could not be determined, however, due to the severe degenerative alterations. There was no significant labelling of lysosomal complexes.

\section{Discussion}

The most novel finding of the present study was the very frequent occurrence of amyloid deposits in the transplanted human islets. Islet amyloidosis is mainly, but not exclusively, a finding of NIDDM, since elderly persons also commonly develop small deposits $[8,10]$. One could argue that some islets might have contained amyloid in the donor pancreata. Islet amyloid is, however, rare in younger persons [8] and in the present series amyloid was found even in islet grafts originating from 18-year-old organ donors. This fact, together with the absence of amyloid in the donor pancreata, indicates that the amyloid was formed after the islet transplantation. A recent study has, however, shown that IAPP can accumulate intracellularly during in vitro culture of human islets and especially during culture at a high glucose concentration [20]. In that report, the nature of the accumulated IAPP was not studied but it seems possible that it was in the form of amyloid fibrils.

The common finding of small but widely spread intra-cytoplasmic amyloid deposits in the present study was unexpected, since islet amyloid occurs almost exclusively as an extracellular alteration but with fibrils running into deep pockets of the beta cells [5]. An intracellular formation of islet amyloid in lysosomes has been proposed [6] but instead of being associated with lysosomes, our findings indicated localisation of the amyloid to structures resembling the endoplasmic reticulum. Whether the findings reflect an in vivo situation in humans remains to be studied, but it may be that intracellularly formed amyloid fibrils are sequestered and act as niduses for further (extracellular) fibril growth [21]. Such a scenario could explain the characteristic amyloid-filled invaginations seen in the beta cells in islet amyloidosis [22].

The occurrence of islet amyloid in humans is strongly associated with NIDDM and it was there- 


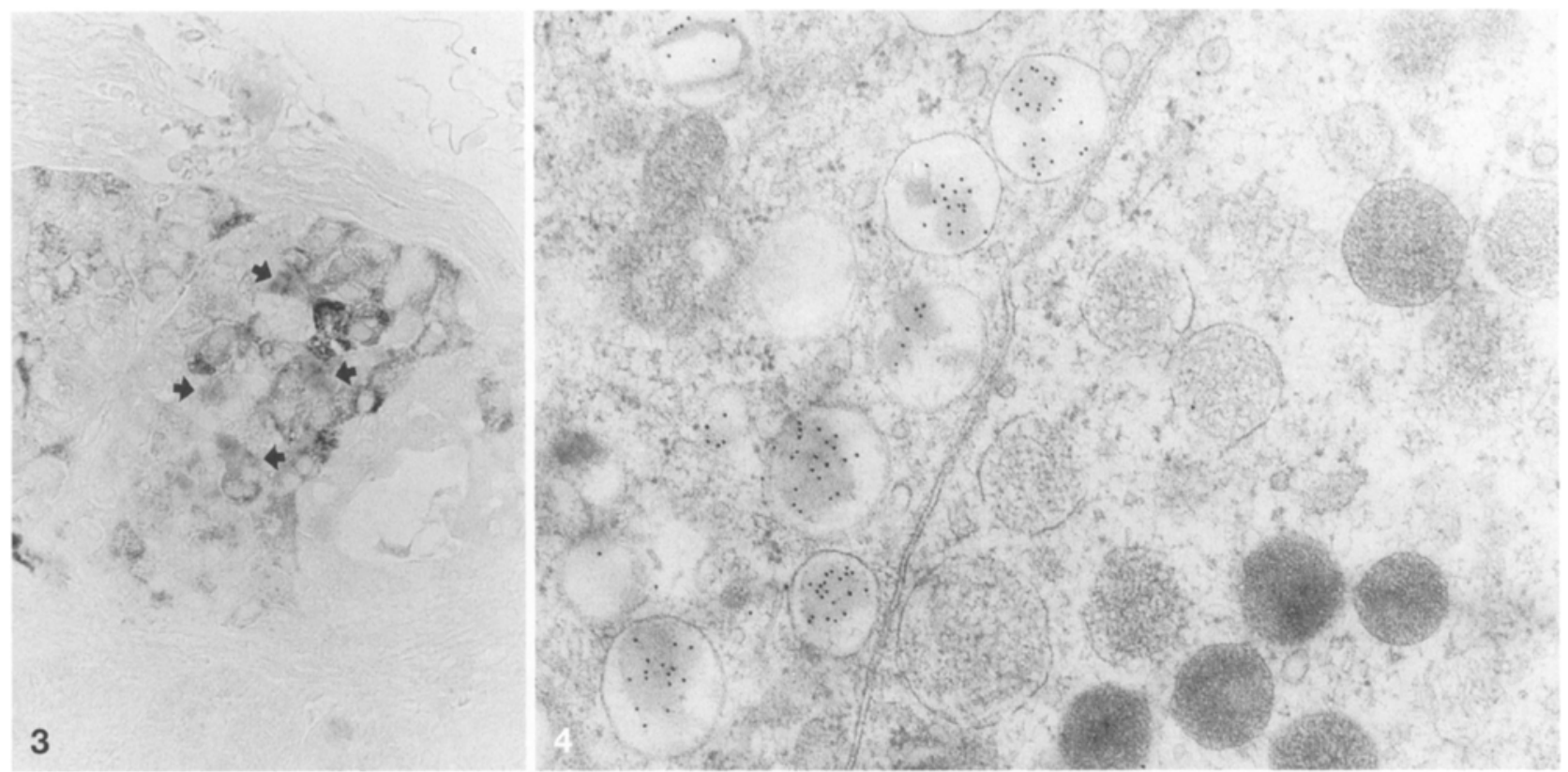

Fig. 3. Human islet transplant, immunolabelled for the demonstration of IAPP. A few strongly IAPP-positive cells are seen. Many small IAPP-positive amyloid deposits occur (arrows). Antiserum to IAPP, peroxidase-antiperoxidase technique. $\times 350$

fore surprising that no difference was found in this respect between islet transplants in diabetic and nondiabetic recipients. This discrepancy cannot be explained at present but does not immediately fit with the theory that the amyloid is a consequence of oversecretion of IAPP in parallel to that of insulin in a state of hyperglycaemia. The finding is potentially important and deserves further study. The lower fraction of IAPP immunoreactive cells in the hyperglycaemic animals is most likely dependent on the marked degranulation seen in many of the beta cells.

There are at present several ongoing clinical programmes for transplantation of isolated human islets for the control of diabetes mellitus. However, so far there has been only moderate success and in most instances the transplants have declined in insulin production. The reason for this is not known. Considering that islet amyloid developed surprisingly rapidly in our experiments, it is conceivable that a similar process takes place also in human islet recipients. Since the first developed amyloid may serve as a nucleus for a cascade of further formation of fibrils $[21,23]$, any degree of islet amyloidosis is a threat against the long-term function of the islet. Islet amyloid has also been proposed to be toxic to beta cells and to cause apoptosis [24] and it is therefore a possible cause of beta-cell deterioration in transplanted islets. The present observation of amyloid in degenerating beta cells fits with this notion.

The early development of islet amyloid has so far been very difficult to study. Indeed, the opportuni-
Fig.4. Electron micrograph showing parts of a beta cell (left) and of a delta cell (right). The secretory granules of the beta cell are labelled with antibodies to IAPP while the delta cell granules are negative. Antiserum to IAPP, protein A-gold technique, $\times 41000$

ties of obtaining pancreatic tissue from living individuals are limited and, therefore, most studies have been performed on autopsy materials from patients with long-standing NIDDM. The initial alterations, which perhaps occur before the development of or early in NIDDM are important to establish since these should better reflect the basic pathogenetic mechanisms than older lesions. Available animal models have been limited to spontaneously diabetic monkeys [25] and cats [26]. The establishment of transgenic mice expressing human IAPP gave a hope of a useful in vivo model. Indeed, several groups have successfully developed such mice, overexpressing human IAPP, but it has not been possible to demonstrate the formation of islet amyloid in these animals $[27,28]$. Interestingly, IAPP-amyloid occurs in islets isolated from transgenic mice and then kept in tissue culture (Westermark et al., unpublished data). The presence of small amyloid deposits in the majority of human islets grafted into nude mice indicates that we now have a very promising and valuable in vivo method by which to study how islet amyloid forms and which effects the deposits may have on islet cell function.

In conclusion, we report here for the first time that human islets grafted into nude mice express IAPP and that the storage of the substance is decreased by hyperglycaemia. The transplants very often develop IAPP-derived amyloidosis and should thus provide an excellent model for studies of islet amyloid pathogenesis. Finally, it would be worth- 


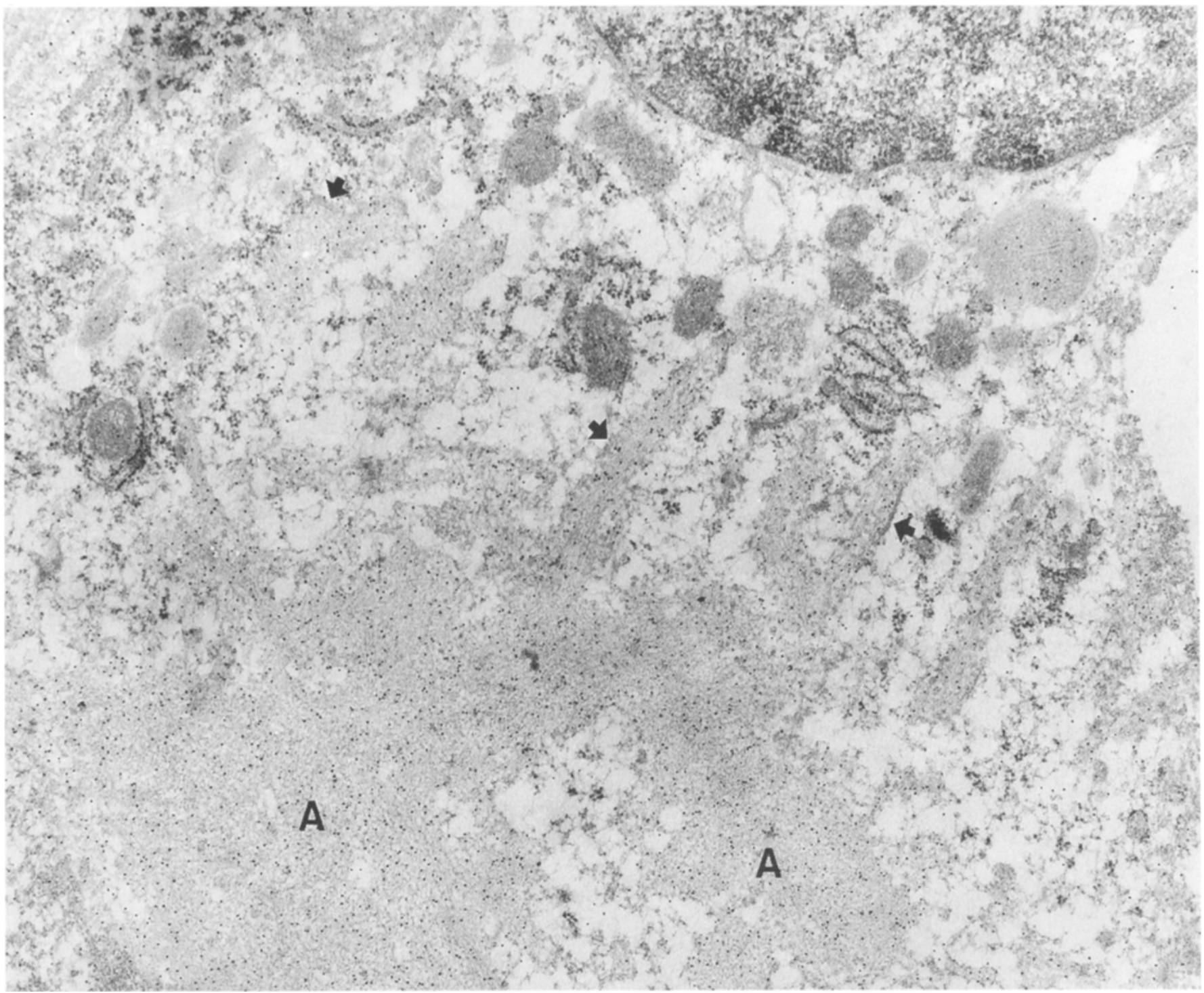

Fig.5. Electron micrograph showing part of a beta cell with severe degenerative changes. Large amounts of amyloid fibrils (A) are seen. The fine fibrils form a tight network. In some areas, structures suggestive of membranes (arrows) seem to delineate the intracellular amyloid. Antiserum to IAPP, protein A-gold technique. $\times 28000$ while to explore to what extent the progressive deposition of amyloid affects the endocrine function of islet transplants.

Acknowledgements. The devoted assistance of C. Bergman, $\mathrm{M}$. Engkvist, M.-L. Eskilsson and A. Nordin is greatly acknowledged. Supported by the Swedish Medical Research Council (Projects No. 12X-5941; 12X9237; 12X-109; 12X-9896; and 19P-8982), the Swedish Diabetes Association, the Juvenile Diabetes Foundation International and the Novo-Nordisk Insulin Fund. Financial support for the human islet project was received from the Commission of the European Community (Biomed BMH1-CT92-0805) and the Belgian and Flemish Ministry (Matching Funds 93/029).

\section{References}

1. Westermark P, Wernstedt C, Wilander E, Sletten K (1986) A novel peptide in the calcitonin gene related peptide family as an amyloid fibril protein in the endocrine pancreas. Biochem Biophys Res Commun 140: 827-831

2. Westermark P, Wernstedt C, Wilander E, Hayden DW, O'Brien TD, Johnson KH (1987) Amyloid fibrils in human insulinoma and islets of Langerhans of the diabetic cat are derived from a neuropeptide-like protein also present in normal islet cells. Proc Natl Acad Sci USA 84: 3881-3885

3. Cooper GJ, Willis AC, Clark A, Turner AC, Sim RB, Reid KBM (1987) Purification and characterization of a peptide from amyloid-rich pancreases of type 2 diabetic patients. Proc Natl Acad Sci USA 84: 8628-8632

4. Westermark P, Johnson $\mathrm{KH}$, O'Brien TD, Betsholtz C (1992) Islet amyloid polypeptide - a novel controversy in diabetes research. Diabetologia 35: 297-303 
5. Westermark P (1973) Fine structure of islets of Langerhans in insular amyloidosis. Virchows Arch. A 359: 1-18

6. Clark A (1992) Islet amyloid - an enigma of type-2 diabetes. Diab Metabol Rev 8: 117-132

7. Gellerstedt N (1938) Die elektive, insuläre (Para-)Amyloidose der Bauchspeicheldrüse. Zugleich ein Beitrag zur Kenntnis der "senilen Amyloidose". Beitr Path Anat 101: $1-13$

8. Bell ET (1959) Hyalinization of the islets of Langerhans in nondiabetic individuals. Am J Path 35: 801-805

9. Westermark P (1972) Quantitative studies of amyloid in the islets of Langerhans. Upsala J Med Sci 77: 91-94

10. Westermark P, Wilander E (1978) The influence of amyloid deposits on the islet volume in maturity onset diabetes mellitus. Diabetologia 15: 417-421

11. Westermark P. (1995) Islet amyloid polypeptide and amyloid in the islets of Langerhans. In: Leslie RDG, Robbins DC, (eds) Diabetes: clinical science in practice. University Cambridge Press, Cambridge, pp, 189-199

12. Westermark P, Grimelius L (1973) The pancreatic islet cells in insular amyloidosis in human diabetic and non-diabetic adults. Acta Path Microbiol Scand [A] 81: 291-300

13. Eizirik DL, Korbutt GS, Hellerström C (1992) Prolonged exposure of human pancreatic islets to high glucose concentrations in vitro impairs the $\beta$-cell function. J Clin Invest 90: 1263-1268

14. Eizirik DL, Pipeleers DG, Ling Z, Welsh N, Hellerström C, Andersson A (1994) Major species differences between man and rodents in the susceptibility to pancreatic $\beta$-cell injury. Proc Natl Acad Sci USA 91: 9253-9256

15. Christmanson L, Betsholtz C, Leckström A et al. (1993) Islet amyloid polypeptide in the rabbit and European hare: studies on its relationship to amyloidogenesis. Diabetologia 36 : $183-188$

16. Westermark GT, Christmanson L, Terenghi G et al. (1993) Islet amyloid polypeptide: demonstration of mRNA in human pancreatic islets by in situ hybridization in islets with and without amyloid deposits. Diabetologia 36: 323328
17 Sternberger LA (1979) Immunocytochemistry, 2nd edn. John Wiley, New York

18. Westermark GT, Norling B, Westermark P (1991) Fibronectin and basement membrane components in renal amyloid deposits in patients with primary and secondary amyloidosis. Clin Exp Immunol 86: 150-156

19. Lukinius A, Wilander E, Westermark GT, Engström U, Westermark P (1989) Co-localization of islet amyloid polypeptide and insulin in the beta-cell secretory granules of the human pancreatic islets. Diabetologia 32: 240-244

20. Novials A, Sarri Y, Casamitjana R, Rivera F, Gomis R (1993) Regulation of islet amyloid polypeptide in human pancreatic islets. Diabetes 42: 1514-1519

21. Jarrett J'T, Lansbury PT (1993) Seeding "one-dimensional crystallization" of amyloid: a pathogenic mechanism in Alzheimer's disease and scrapie? Cell 73: 1055-1058

22. Westermark P (1994) Amyloid and polypeptide hormones: what is their inter-relationship? Amyloid 1: 47-60

23. Ashburn TT, Lansbury PT (1993) Interspecies sequence variations affect the kinetics and thermodynamics of amyloid formation: peptide models of pancreatic amyloid. J Am Chem Soc 115: 11012-11013

24. Lorenzo A, Razzaboni B, Weir GC, Yankner BA (1994) Pancreatic islet cell toxicity of amylin associated with type-2 diabetes mellitus. Nature 368: 756-760

25. Howard CFJ (1978) Insular amyloidosis and diabetes mellitus in Macaca nigra. Diabetes 27: 357-364

26. Johnson KH, Stevens JB (1973) Light and electron microscopic studies of islet amyloid in diabetic cats. Diabetes 22: $81-90$

27. Fox N, Schrementi J, Nishi M et al. (1993) Human islet amyloid polypeptide transgenic mice as a model of non-insulin-dependent diabetes mellitus (NIDDM). FEBS Lett 323: 40-44

28. Höppener JWM, Verbeek JS, de Koning EJP et al. (1993) Chronic overproduction of islet amyloid polypeptide/amylin in transgenic mice: lysosomal localization of human islet amyloid polypeptide and lack of marked hyperglycaemia or hyperinsulinaemia, Diabetologia 36: 1258-1265 